Patrizia Moselli

A Window on the Pandemic Emergency: Reflections and Actions

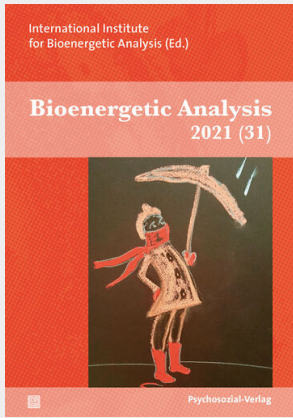

Bioenergetic Analysis

31. Volume, No. 1, 2021, Page 49-57

Psychosozial-Verlag

DOI: 10.30820/0743-4804-2021-31-49 
Reviewers for this issue:

Léia Cardenuto, Garry Cockburn, Maê Nascimento and M. Rosaria Filoni

Translators of abstracts for this issue:

Angelina Samartova (Russian), Claudia Ucros (French), Karin de Marval (Spanish), Maê Nascimento (Portuguese), Maria Rosaria Filoni (Italian), Thomas Heinrich (German) and Rebecca Jianpu Liu (Chinese)

Submissions for consideration for the next volume of Bioenergetic Analysis must be sent to Maê Nascimento (maenascimento@terra.com.br) between June $1^{\text {st }}$ and September $1^{\text {st }}$, 2021.

Bibliographic information of Die Deutsche Nationalbibliothek (The German Library) The Deutsche Nationalbibliothek lists this publication in the Deutsche Nationalbibliografie; detailed bibliographic data are available at http://dnb.d-nb.de.

2021 Psychosozial-Verlag, Gießen, Germany

info@psychosozial-verlag.de

www.psychosozial-verlag.de

\section{(C) $(1) \Theta$}

This work is licensed under the Creative Commons Attribution-NonCommercialNoDerivatives 4.0 International License (CC BY-NC-ND 4.0). This license allows private use and unmodified distribution, but prohibits editing and commercial use (further information can be found at: https://creativecommons.org/licenses/by-nc-nd/4.0/). The terms of the Creative Commons licence only apply to the original material. The reuse of material from other sources (marked with a reference) such as charts, illustrations, photos and text extracts may require further permission for use from the respective copyrights holder.

Cover image: Vincentia Schroeter, Umbrella girl (c) Vincentia Schroeter Cover design \& layout based on drafts by Hanspeter Ludwig, Wetzlar Typesetting: metiTec-Software, me-ti GmbH, Berlin, www.me-ti.de

https://doi.org/10.30820/0743-4804-2021-31

ISBN (PDF-E-Book) 978-3-8379-7809-4

ISBN (Print) 978-3-8379-8363-0

ISSN (Online) 2747-8882 • ISSN (Print) 0743-4804 


\title{
A Window on the Pandemic Emergency: Reflections and Actions
}

\section{The Contribution of Bioenergetic Analysis}

\author{
Patrizia Moselli
}

Bioenergetic Analysis • The Clinical Journal of the IIBA, 2021 (31), 49-57

https://doi.org/10.30820/0743-4804-2021-31-49

CC BY-NC-ND 4.0

www.bioenergetic-analysis.com

\section{Abstracts}

The article can be defined in two parts. The first concerns a more personal reflection on the meaning of the lockdown experience for me. The second part, on the other hand, represents a more theoretical reflection on online sessions and on those therapeutic factors that affect the possibility of having meaning, transformation and change, even though this modality is quite "new" for me and for many bioenergetic psychotherapists. This article highlights that every therapeutic act starts from empirical experience and then the elaboration allows the transformation of the theoretical and sensory boundaries.

Keywords: empathy, somatic and energetic autoregulation, relationship, grounding

Uma janela para a emergência da pandemia. Reflexões e ações, a contribuição da análise bioenergética (Portuguese)

$\mathrm{O}$ artigo compreende duas partes. A primeira é uma reflexão pessoal do autor sobre o que significou a experiência do confinamento para si. A segunda parte é uma reflexão teórica do autor sobre aos fatores que influenciam na possibilidade de dar significado, transformação e mudança na sessão online, sendo esta uma modalidade nova para si, e para muitos outros terapeutas. Este artigo salienta que todo ato terapêutico começa na experiência empírica para então proceder à elaboração que permitirá a transformação tanto da teoria quanto das fronteiras sensoriais.

Una ventana en la emergencia de la pandemia. Reflexiones y acciones, la contribución del Análisis Bioenergético (Spanish)

El artículo se define en dos partes. La primera es una reflexión personal sobre el significado de la experiencia del confinamiento (lockdown) para mi. La segunda parte, por otro lado, 
representa una reflexión teórica sobre las sesiones online y sobre los factores terapéuticos que afectan la posibilidad de dar significado, transformación y cambio, mismo en estas modalidades "nuevas" para mi y para la mayoría de los psicoterapeutas bioenergéticos. Este artículo destaca que cada acto terapéutico comienza en una experiencia empírica y que su elaboración permite la expansión de las fronteras teóricas y sensoriales.

Una finestra sull'emergenza pandemica. Riflessioni e azioni, il contributo dell'analisi bioenergetica (Italian)

L'articolo può considerarsi composto da due parti. La prima è una riflessione personale su cosa ha significato per me l'esperienza del lockdown. La seconda parte è una riflessione teorica sulle sedute online e sui fattori terapeutici che influenzano la possibilità di dare significato, trasformazione e cambiamento nonostante questa modalità piuttosto "nuova" per me e per molti terapeuti bioenergetici. Questo articolo mette in luce che ogni atto terapeutico parte dall'esperienza empirica e che l'elaborazione permette la trasformazione dei confini teorici e sensoriali.

Une fenêtre sur la crise pandémique. Réflexions et actions, la contribution de l'Analyse Bioénergétique (French)

L'article comporte deux parties. La première concerne une réflexion plus personnelle sur la signification de l'expérience du confinement pour moi. La seconde partie, par ailleurs, représente une réflexion plus théorique sur les séances en ligne et sur les facteurs thérapeutiques qui affectent la possibilité d'avoir un sens, une transformation et un changement, même si cette modalité est assez "nouvelle" pour moi et pour de nombreux psychothérapeutes bioénergétiques. Cet article souligne que tout acte thérapeutique débute par une expérience empirique et que son élaboration permet ensuite de transformer les frontières théoriques et sensorielles.

\section{Ein Fenster zum pandemischen Notfall. Gedanken und Maßnahmen. Der Beitrag der bioenergetischen Analyse (German)}

Der Artikel kann in zwei Teile gegliedert werden. Der erste betrifft eine eher persönliche Reflexion über die Bedeutung der Lockdown-Erfahrung. Der zweite Teil hingegen stellt eine eher theoretische Reflexion über Online-Sitzungen und über jene therapeutischen Faktoren dar, die die Möglichkeit beeinflussen, Bedeutung, Transformation und Veränderung zu erfahren, auch wenn diese Modalität für mich und für viele bioenergetische Psychotherapeut innen ziemlich "neu” ist. Dieser Artikel hebt hervor, dass jeder therapeutische Akt von der empirischen Erfahrung ausgeht und anschließend das Herausarbeiten die Transformation der theoretischen und sensorischen Grenzen ermöglicht.

\section{Широкий обзор опасностей пандемии. Размышления и действия, вклад в биоэнергетический анализ (Патриция Мозелли) (Russian)}

Статья делится на две части. Первая содержит мои глубоко личные размышления о том, что несет опыт локдауна. Вторая же представляет собой 
теоретические размышления о сеансах онлайн и о терапевтических факторах, влияющих на значение, трансформацию и изменение, даже если такой способ для меня и многих биоэнергетических психотерапевтов достаточно “новый”. В статье подчеркивается, что каждый терапевтический акт начинается с эмпирического переживания, его дальнейшая переработка позволяет трансформацию теоретических и сенсорных границ.

疫情危机下的窗口。关于躯体动力分析的贡献的反思与行动 (Chinese)

本文分为两个部分，第一部分是关于我在疫情下禁足体验的个人反思；第二部分，是关于线上个 案的理论性思考，尤其是那些影响到意义、转化和改变的理论性因素。无论如何这些改变对于我 和很多躯体动力分析治疗师来说都是很“新”的。本文强调了每一个治疗方法都自体验开始，而后的 复杂性促使了理论和感知界限的转化。

\section{Introduction}

We have been going through a very difficult phase of our experience. The pandemic situation and the consequent restrictive measures have presented us with new challenges, both as individuals and as professionals. So, this situation has given me the opportunity for deep reflection. My perception has been that Italian people, in particular, tried to respond with so much humanity, so much force, and also so much resilience to a very hard historical moment.

With this contribution, I intend to describe how bioenergetic analysis, in these difficult circumstances, helped us. So how has bioenergetic analysis responded to this new dimension that characterized this emergency health situation?

We should start from the fact that we must not lose faith in self-regulating and vital forces, even if we are forced to remain closed-in at home and to "suspend" all those dimensions that are natural for us. I was thinking back to when I interviewed Alexander Lowen in Corfu, Greece, in May 1994. He had recently written Joy: Surrender to the Body and had already dealt with this theme in his book Narcissism (1985). In this later book, Lowen underlined the problems of individual narcissism, and importantly, he highlighted the cultural and social narcissism in which the individual is embedded. Already in the 1980s, Lowen had highlighted the danger concerning the actual living situation, in terms of "nocontact", in terms of disconnection from our body, from our emotions and from our vital energy. He said that "maybe a disaster will bring everyone back in touch with their humanity." Many years have passed, and perhaps we have been experiencing that "disaster" mentioned by Lowen. 


\section{The current crisis}

A great crisis, one of the most serious ever experienced, has occurred. A crisis not only concerning Italian people, but a worldwide crisis, which demands we reconsider all that we have taken for granted, and also that which has not been taken for granted. Everything that was considered free, such as freedom of movement, has now become a really basic need of the individual. Inevitably, this situation leads us to review all those values and dimensions that we consider essential in our life.

Therefore, we cannot underestimate this new condition of "staying closed": we are now living in a condition of effective closure, due to the mandatory quarantine. And this new dimension of needed - but forced - closure, has now allowed us to reflect on what is important for us, and how we can still feel free and vital even if our freedoms have been restricted.

We have had to stay indoors to protect ourselves and the others, but also, we have had to remain open to meet others in other ways, and in some way to continue to "travel", if not with our physical body, then with our spiritual body. It has been essential to keep this connection with ourselves alive, as well as with our loved ones.

I believe it has been significant, for us psychologists, to respond to the needs of our clients in the way they were expressed. This might have meant respecting their will to remain isolated, even to stop the therapy, or their desire to see us if this was important for them. I also believe it was essential not to avoid the patient's request to meet in person, because basically we practice a socio-health profession.

Anyway, the lockdown situation has led many of us, psychotherapists in bioenergetic analysis, to review many of our ideas and opinions about online psychotherapy. It is a bit like rediscovering the wisdom of that popular saying: "to make a virtue of necessity".

I continued to hold sessions in person (which still represents my favorite way to operate in the clinic), respecting each other's borders and health regulations. But I also felt the importance of respecting the needs of those patients who, while wanting to respect the total lockdown, did not want to stop psychotherapy and who therefore asked me to meet in online settings. Therefore, this mode has certainly been "a novelty" to me.

In the past, I have always discouraged online psychotherapy, as well as supervision sessions. When patients moved to another place and asked to continue psychotherapy via internet, I have always encouraged them to search for another psychotherapist in the area in which they were living.

This rigidity of mine has been rather longstanding. It has expressed, in some way, a deep distrust of this form of psychotherapy. Looking back on this position of mine, I am able to realize that my position did not start from "experience" but rather from value biases about psychotherapeutic work. Abstract ideas or ideology should not guide theory, since there is the risk of the theory not being 
thoroughly grounded in reality. In this emergency health situation, where reality has "imposed" new perspectives on us, what should always happen in the clinic has happened: experience, and not theory, has been given priority. Just think of Freud, Rogers, Reich, Lowen - all those masters who started out from their clinical experience and then derived their theories from their practice.

\section{Reflections on Practice}

I have produced some reflections from my experience with online sessions with patients with whom I have previously had face-to-face sessions. I have no experience with patients with whom I started online psychotherapy, and so I cannot reflect on that type of situation.

The first important observation is precisely on the centrality of the therapeutic relationship and the co-construction of a meaningful setting for both the patient and the therapist. It is in fact the mutual intentionality of patient and therapist that makes the exchange meaningful. The therapist's ability to be centered and attuned to the patient, is even more decisive in online sessions, where any "floating" attention, or reverie, risks making connection with the other almost impossible. In fact, it is very easy for the other person to switch to an "offline" mode if the therapist's constant attention is lacking.

It was important for me to find out how much my Rogerian training helped in this phase. The careful use of words, the reflecting-back of experiences and feelings, as well as empathic listening, were all elements that formed a frame of reference to help create a meaningful setting. Empathy, as an element that goes beyond the boundaries of the ether, suddenly made the other "close".

Another aspect that guided my being "active" as a psychotherapist, is more related to my experience in bioenergetics analysis and its basic assumption: "trust in the body and in its self-regulating functions". This trust helped me to risk using interventions on the body, even without all those elements that guide the therapist in the sessions in presence (the ability to perceive the energy, the complexion, the most visible light in the eyes, etc.).

It was fascinating to observe the collaboration of my clients and to note the trust they gave to interventions not mediated by my physical presence, but rather linked to their ability for self-perception, their ability to deepen their breathing, and even to scream when they felt the need. Somehow it seemed to me that they expanded their capacity for an internal "locus of control". It was clear in these moments that my attention on their "window of tolerance" had been even stronger, and that this attention had allowed me to help them modulate the experiences I proposed.

The focus on my body's experience has guided me to feel less concern about the distance of the other and feeling more capable of helping the other. The ther- 
apist must be even more capable of developing that "internal space" to feel the other close to herself: body empathy is still a co-construction between therapist and patient.

A fundamental aspect that I have noticed as being more relevant in online settings than in face-to-face ones, is the concern about "image". If it becomes problematic for the therapist, it will almost certainly become problematic for patients. The psychotherapist never has to worry about her/his image. She/he should rather seek the "spirituality" of the image in the other and in herself/himself. It is as if the "ethereal" body should emerge on the virtual body.

It is also important to remember that our clients are content and guided not only in the cognitive aspects of the interaction, but also, and above all, in those aspects of "paraverbal communication" which have always been fundamental in the therapeutic moment. In fact, we need to keep in mind, and even more so in the online mode, that the patient will not only respond to the content of our words, but also to the tone of our voice, to our ability to look at them "truly" in a different way. We need to be close even in the distance and despite the distance of the other.

"My voice will accompany you." This sentence makes me think of how online sessions can help the patient to manage distance. I like to mention it for this reason. The phrase is the title of a book by Milton Erickson (1981), and, although is not a novelty in the field of psychotherapy, it highlights how universal it is to all psychotherapeutic approaches. The phrase is a reflection of the quality of the psychotherapist's "presence", both real (face-to-face) and virtual. However, the virtual presence that can never replace the richness of the other's corporeity.

To me, Skype sessions are therefore an alternative tool, which has allowed and allows everyone to remember the importance of the relationship, even in situations that make "the presence" impossible. But I also believe that, especially in this post-pandemic phase, therapists have the task of motivating the patients to get out of isolation and therefore to make them rediscover the pleasure of contact and relationship with each other.

We are experiencing a very important moment in our history: a radical change is taking place, also in the way we perceive our body and that of the others. The body can in fact be perceived as vulnerable and threatened by the body of the other, that is seen as a potential "enemy". The risk is of falling into a spiral of social paranoia that we should absolutely avoid. The fundamental function of the psychotherapist (in particular of a body psychotherapist) is therefore to keep attention on the body and to keep somatic perception alive in the patient. Our body must become, more now than ever, a guiding tool that protects us.

Therefore, the analogy with the phases of our breathing and with the selfregulating process of our cells is relevant. It indicates the naturalness of movement, characterized by the modulation between "contraction" and "expansion", between closure and opening. We must refer to this energetic modulation and, 
through it, we have to go back to our body as a true "safe basis" of our acting and feeling. The image of our energy flows, therefore, becomes a metaphor for our learning to live, every day, with the potential "dangers" of the coronavirus.

\section{So how can Bioenergetic Analysis help us in this situation?}

Bioenergetic analysis can help because it is an approach intimately tied to our vitality and therefore to our resilience. Vitality is something that we must exercise not only if we move outwardly, but it is something that we must cultivate inside. We have had time to stop, to reflect, to breathe more deeply, to contact our body. Perhaps it is precisely because our rhythms have slowed down that we can have a greater chance of a different type of contact with our body. Surely, we can practice more of these things than when our busy lives did not allow us to do.

I remember, for example, when I met Alexander Lowen for personal therapy for the first time, many years ago, and on that occasion, he reminded me that, in order to keep the vital energy alive, it was necessary to exercise daily, using the voice and then opening the breath and the diaphragm, precisely to increase energy and therefore our level of vitality. In using our voice we also activate our life force.

During these hard times, we certainly do not need to be depressed. We need our assertiveness and our natural aggression. So, for example, if we feel the need to scream, we can raise our voice. It would be interesting to see how this might help in keeping our inner resources alive. I can recommend all those exercises that Alexander Lowen suggested as a good daily practice.

It is also a time to spend reading, and it has been a good opportunity to review all of Alexander Lowen books, reading them again, through the light of the acquired knowledge. We have had more time to stay online, and therefore we have had more time to watch all the Lowen videos and others related to bioenergetic analysis in general. This has allowed us, as well as our students and all those who practice bioenergetic analysis, to gather a moment for deeper reflection on and analysis of all those fundamental issues.

\section{Contact and support: the work of SIAB in COVID-19 times}

It has been very important, in these difficult times, to understand, even more so, the value of physical contact, so fundamental a characteristic, especially for Italians. It has been necessary, therefore, to ask ourselves about the importance of physical contact in therapy. While "contact" was forbidden, we had the chance to reflect on our psychotherapy, which is a body psychotherapy. And it is also 
through the mediation of contact that we give so much support to clients. I have also found the topic of contact as a source of "social engagement" very interesting. Contact characterizes Italians so much and we have had to repress this national characteristic. This fact has also let us to reflect on how contact is such a strong therapeutic agent. This particular reflection became relevant, in considering a further investigation about the specificity of our bioenergetic approach.

In times of emergency and crisis, the desire to be useful, to really give support to others, increases. At SIAB, we have activated, thanks to our prior experience, a free online service for psychological support to all those doctors, nurses and all those who were involved in the front line with the coronavirus emergency. It was also available to those who felt frightened or suffocated by this dimension of limited freedoms or felt the need for some help in this very difficult period.

Through \#Noicisiamo - the name of the project - we wanted to attest our presence on the national scene. It was presented through a video made in collaboration with IIIBA and posted both on SIAB Facebook and IIBA Instagram. In this video there were also some reflections of mine about these times of social distancing.

SIAB also took part, through the Italian Federation of Associations in Psychotherapy (FIAP), in an important project activated by the Italian Ministry of Public Health. We remained the only Society in FIAP who decided to continue this important collaboration, answering the Ministry's request to extend this service for a little longer period.

SIAB also activated two relevant partnerships and offered a service of psychological support ( 4 free sessions) through its Clinical Center. The first was to the employees of one of the biggest communication company in Europe (TIM); and the second to the employees of the Airport Company of Rome (ADR), which is the most important airport company in Italy, and the $5^{\text {th }}$ largest in Europe.

Every week there was also an online supervision meeting with all the psychotherapists of the SIAB Clinical Center - the SIAB "Psychological Support Project". This was a way to monitor the activity in order to keep ourselves united and tied together with the power of a great collective embrace. This was our response to "isolation" - being socially active and staying connected. So, our community proved to be very "solid" in facing this crisis situation. We all believe that unity is the real strength.

We have had a continuous exchange of reflections and sharing of activities. Many of our members did classes of bioenergetic movement online and they were promoted on the SIAB Facebook page. Our blog's editorial staff was active and worked on articles about this emergency to post online. I was interviewed "live" on Facebook, by a SIAB member, Luca Castellano, from Colombia, and talked about bioenergetic analysis in COVID-19 times.

We also started teaching our training course online, making the lessons as accessible as possible. Our students demonstrated great resilience, using a lot of 
effort following online lessons and remaining strongly motivated. This new tool has now been adopted and it has certainly been an excellent stimulus for reflection. The teaching committee met online, and it has been an occasion to share our impressions about teaching and practice online at an international level.

In conclusion, my thoughts go to the postponed conference that was due to be held in Brazil, and I hope we can find a way to meet internationally online. Anyway, I remain positive and strongly believe that there will be occasions to meet again face-to-face, in the not-too-distant future, and to share the richness of our therapeutic visions, that allow us to confirm, as a common fact, the importance of psychotherapy in today's society.

\section{References}

Biondi, M., \& lannitelli A. (2020). COVID-19 e stress da pandemia: "I'integrità mentale non ha alcun rapporto con la statistica" (COVID-19 and stress in the pandemic: "sanity is not statistical"). Rivista di Psichiatria, 55(3), 131-136. doi 10.1708/3382.33567

Lowen, A. (1970). Pleasure: A creative approach to life. New York: Penguin.

Lowen, A. (1975). Depression and the Body. New York: Penguin.

Lowen, A. (1975). Bioenergetics. New York: Coward, McCarin \& Georgen Inc.

Lowen, A. (1980). Fear of Life. New York: Macmillan.

Lowen, A. (1984). Narcissism: Denial of the true self. New York: Macmillan.

Lowen, A. (1994). Joy: Surrender to the body. New York: Penguin.

Lowen, A., \& Lowen, L. (1977). The Way to Vibrant Health: A manual of exercises. New York: Harper \& Row.

\section{Sitography}

https://www.bioenergetica-lowen.it https://www.facebook.com/AnalisiBioenergeticaLowen https://www.rivistadipsichiatria.it

\section{About the Author}

Patrizia Moselli, Psychologist, Psychotherapist. International trainer and member of the Board of Directors and Faculty of IIBA (International Institute for Bioenergetic Analysis), President of SIAB (Italian Society of Bioenergetic Analysis) and Past President of FIAP (Italian Federation of Psychotherapy Associations). Senior trainer also in the person-centered approach. Author of books and articles for clinical journals.

mail@siab-online.it 